$\begin{array}{r}\text { Volume and Issues Obtainable at Center for Sustainability Research and Consultancy } \\ \text { Journal of Business and Social Review in Emerging Economies } \\ \text { ISSN: 2519-089X (E): 2519-0326 } \\ \text { Volume 6: No. 4, December 2020 } \\ \text { JSRᄃ } \\ \text { Journal homepage: www.publishing.globalcsrc.org/jbsee } \\ \hline\end{array}$

\title{
Awareness on Islamic Banking: An Investigation on Women Entrepreneurs in Quetta
}

\author{
${ }^{1}$ Saba Raja, ${ }^{2}$ Jameel Ahmed, ${ }^{3}$ Kaneez Fatima \\ ${ }^{1}$ Research Student, Institute of Management Sciences, University of Balochistan, Quetta, Pakistan, \\ sabaraja28@yahoo.com \\ ${ }^{2 \& 3}$ Assistant Professor, Institute of Management Sciences, University of Balochistan, Quetta, Pakistan, \\ jamil.ahmed@um.uob.edu.pk, fatima.sohail@ hotmail.com

\begin{tabular}{l}
\hline ARTICLE DETAILS \\
\hline History \\
Revised format: November \\
2020 \\
Available Online: December \\
2020 \\
\hline Keywords \\
Women entrepreneurs, \\
Awareness, Islamic Banking, \\
Islamic Banking Products, \\
Quetta. \\
\hline
\end{tabular} \\ JEL Classification \\ MO, $M 1$

\begin{abstract}
This study creates the profile of women entrepreneurs in Quetta city and examines their awareness level regarding Islamic banking and its products. The study is descriptive in nature and survey questionnaire was used for data collection. The data from 106 women entrepreneurs were collected who are engaged in multiple business activities in Quetta city. From the results it has been found that majority of the women entrepreneurs (i.e., 60\%) knew about the term, Islamic banking but the sample size trimmed down as the research questions moved to awareness about Islamic principles, Shariah board, Islamic banking products, Islamic modes of finance and comparison of Islamic banking with conventional banking. It was found that only 10 (out of 106) women entrepreneurs are highly aware about Islamic banking, Islamic principles, Shariah board, Islamic banking products, and Islamic modes of finance. This study suggests that Islamic banks, scholars, and academicians should collaborate to enhance the awareness by arranging awareness campaigns, workshops, seminars, and training sessions on Islamic banking and its products among women entrepreneurs.
\end{abstract}

(C) 2020 Center for Sustainability Research and Consultancy Pakistan under a Creative Commons Attribution-NonCommercial-ShareAlike 4.0

Corresponding author's email address: sabaraja28@yahoo.com

Recommended citation: Raja, S., Ahmed, J. \& Fatima, K. (2020). Awareness on Islamic Banking: An Investigation on Women Entrepreneurs in Quetta. Journal of Business and Social Review in Emerging Economies, 6(4), 1595-1609

\section{Introduction}

Islamic finance implies the financial structure in which all financial activities must comply with Shariah (Reiff, 2018). The concept of Islamic finance came into being with the inception of Islam, but formally Islamic banking system was established in the 20th century. It provides an interest-free banking system and operates according to Shariah (Gait \& Worthington, 2007). Islamic banking is rapidly growing in the international market. Currently, more than 300 Islamic banks are operating in over 50 countries around the world (Lim, 2019) and more than 200 conventional banks are offering Islamic banking services from their Islamic windows (Markets, 2019). 
In Pakistan, the Islamic banking system was initiated with the establishment of Meezan bank in 2002. Currently, five Islamic banks and 16 conventional banks with Islamic windows are functioning in the country (SBP, 2019). The annual growth rate of the Islamic banking is $17 \%$ in Pakistan. The market share of Islamic banking in total assets and deposits of banking industry has grown to $13.5 \%$ and $15.5 \%$ respectively in 2018. However, the market share is still low in comparison to conventional banks which indicates that there is enormous potential for growth of Islamic banking in Pakistan (Islamic Banking Bulletin, 2018).

To expand the market share, Islamic banks need to provide an extensive range of financial products and facilities to serve a large group of consumers. In Pakistan, currently, Islamic banks are providing financing in three sectors, which are corporate, consumer and SME sector. Figure-1 shows the sectorwise financing by Islamic banks. It is evident from the figures that financing to the corporate sector is high in overall financing while financing to SMEs is very low throughout the period (Islamic Banking Bulletin, 2020). Islamic banks may increase their share substantially by paying attention to the SME sector as it is one of the major sectors which captures the $90 \%$ of business in Pakistan, contributes nearly $40 \%$ in GDP and provides employment to $80 \%$ of the non-farming workforce (Iqbal, 2019).

Figure 1. Sector wise financing portfolio (\% shares)

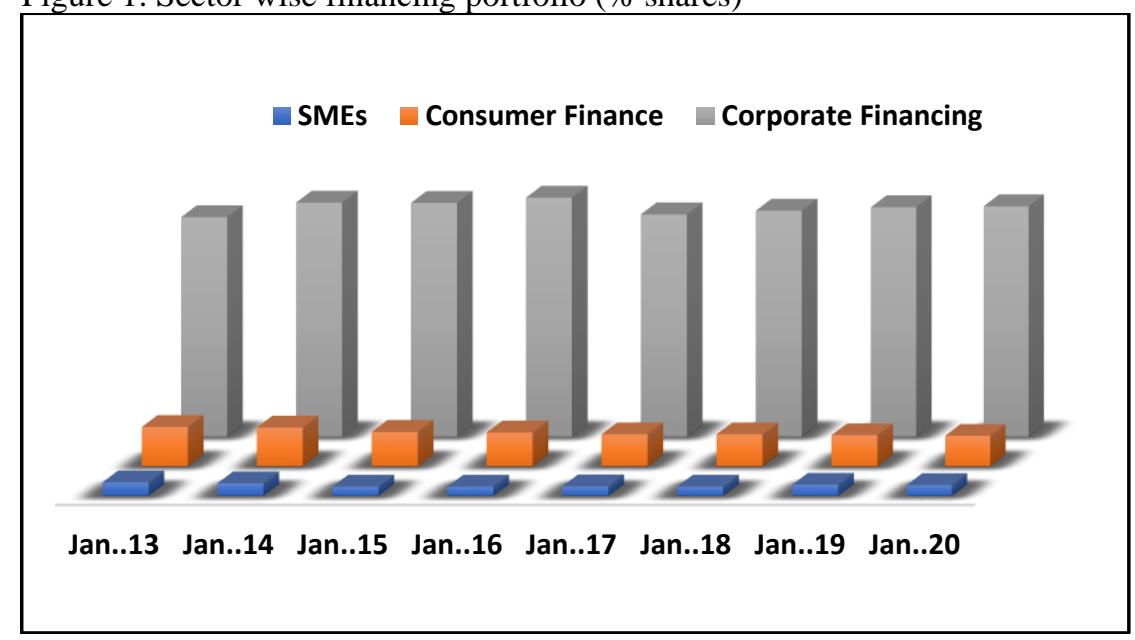

Source: (Islamic Banking Bulletin, 2020)

In the SME sector, women entrepreneurs are also playing an essential role and has immense potential to contribute to the development of society and economic growth (Susruthan \& Priyadharshany, 2018). In Pakistan, the number of women entrepreneurs is growing at good pace (Kazmi, 2018).

However, in Pakistan, women are disproportionately under-served by the country's financial system as only $25 \%$ of the total unique bank accounts are owned by women. This situation is bleaker in case of Balochistan which may be attributed to poverty, cultural or religious values. This act as a major impediment in economic and social development. To address this gap, State Bank of Pakistan has developed a Gender Mainstreaming Policy "Banking on Equality: Reducing the Gender Gap in Financial Inclusion" that aims to promote women financial inclusion in Pakistan (State Bank of Pakistan).

Islamic banks may play an important role in this regard by focusing on financial needs of women entrepreneurs to run their businesses smoothly. This will increase the market share of Islamic banks in the industry and their contribution towards economic growth and development. To serve this purpose, Islamic banks must have knowledge about the awareness level of individuals in the market about Islamic banking. They must take measures to create basic awareness about the products and services they are offering to the customers and make them understand how Islamic banks are different from conventional banks. 
There have been many studies conducted to examine the attitudes and awareness of customers, university graduates and bank employees about the Islamic banking (Hidayat et al., 2020; Lujja et al., 2018; Ahmed, Bano \& Dawood, 2017; Ahmad et al., 2015; Chowdhury \& Arifuzzaman, 2013; Khafafa \& Shafii, 2013; Göksu \& Becic, 2012; Khattak \& Rehman, 2010; Metawa \& Almossawi, 1998; Haron et al., 1994). There have also been few studies conducted on business firms, corporations, and SMEs' attitudes towards the Islamic financial system (Gait \& Worthington, 2008). However, no study in literature has investigated the awareness level of women entrepreneurs about Islamic banking. Thus, this study aims to investigate the awareness level of women entrepreneurs about Islamic banking and its products in Quetta, Pakistan. The study will contribute to literature in several ways; First, it focuses the women entrepreneurs of Quetta where, no profile of the women entrepreneurs was available with SMEDA or any other Govt Organization. Hence, we create their profile. Secondly, it determines the degree of awareness of women entrepreneurs on Islamic banking, and its products and the difference between Islamic and conventional banking.

The rest of the paper is organized as follows; Section 2 reviews the literature briefly, section 3 lays out the methodology, section 4 presents the analysis of results, section 5 concludes.

\section{Literature Review}

Islamic banking system is characterized as banking system which is in line with Islamic values and governed by the Shariah principles (Cheteni, 2014). Fundamentally, Islamic banking system is introduced to fulfill the requirement of Muslims to use banking products/services in such a way that doesn't comprise the Islamic values (Khan et al., 2007). Islamic banking is rapidly growing in last few decades and expended to all places in world-wide and it has gained extensive recognition among Muslims and Non-Muslims (Ahmad et al., 2015).

\subsection{Awareness about Islamic Banking}

Awareness refers to the knowledge or information about the particular object (Yaur, 1973). Awareness towards Islamic banking and its products refers to the knowledge and understanding about the existence of Islamic bank, as well as information about its operations, product/services and all functions of Islamic banking (Buchari et al., 2015a). In literature, number of studies (for example Hidayat et al., 2020; Ahmed, Bano \& Dawood, 2017; Ahmad et al., 2015; Chowdhury \& Arifuzzaman, 2013; Göksu \& Becic, 2012; Haron et al., 1994) have been conducted on the awareness level of customers, employees, entrepreneurs, students of graduate studies, university employees, and Muslims and Non-Muslims communities. These studies have been conducted in various countries around the world including Bahrain, Jordan, Bangladesh, Brunei, Libya, South Africa and in several cities of Pakistan.

The previous studies show that majority of customers were aware with the term, 'Islamic banking' (Saini et al., 2011). However, they were less aware with the products and services provides by Islamic banks (Metawa \& Almossawi, 1998). The customers were using it for daily transactions therefore they were aware only with some general products including current/saving accounts, Automated Tailored Machine (ATM), and the rest were unfamiliar with other products offered by Islamic banking (Imran et al., 2014; Raza \& Azeem, 2014). Similarly, the majority of the respondents were not aware with several financial products such as Mudarabaha, Musharkaha, Murhabaha and Ijarah (Khan et al., 2007). Naser et al. (1999) found that majority of the customers have switched to Islamic banking due to religious motivation. The religious motivation is one of the important factors while choosing Islamic banking, whereas the other factors including confidentiality of customers' information, transaction efficiency, services charges, and financial counseling played a significant role in choosing Islamic banking (Khattak \& Rehman, 2010). On the contrary there were few customers who had skeptical views regarding the Shariah compliance of Islamic banking (Imran et al., 2014). The few studies suggested that marketing strategies should be improved to boost the customer's awareness regarding Islamic banking products as the majority of the respondents were unaware with Islamic banking products and financial products (Bashir, 2013; Khafafa \& Shafii, 2013). 
Similarly, few studies have been conducted on awareness of financial institution's employees. These studies have been conducted in Bahrain, Russia, and Pakistan. The study in Bahrain shows that more than half of the participants were aware of Islamic banking, and have positive perspective for Islamic banking products (Buchari et al., 2015b). On the other hand, the study in Russia found that there is a relatively low level of awareness among employees of financial institutions. The respondents were not aware that Riba, Maysir and Gharar strictly prohibited in Islam. Likewise, the respondents were not aware of financial products, even they were not familiar with the terminologies used in modes of finance (Hidayat et al., 2020). Furthermore, in comparison to the employees of Islamic banks and Conventional banks having Islamic windows, the employees of Islamic banks are more aware with the operations, products and services of Islamic banks than their conventional counterparts (Arshad et al., 2011; Zainol, 2008). It has also been found that the gender and age pay a significant role in terms of awareness of employees (Buchari et al., 2015b; Saleem et al., 2018).

Furthermore, few studies have also been conducted on university graduates regarding their awareness about Islamic banking. These studies found that majority of respondents have a lack of understanding about Islamic banking and they were unfamiliar with the products offered by Islamic banks (Ali, 2016). Due to lack of understanding, the respondents had skeptical views regarding Shariah compliance activities of Islamic banking (Chowdhury \& Arifuzzaman, 2013).

The review of literature shows that the studies are conducted on awareness level of customers, employees, entrepreneurs, students of graduate studies, university employees, and Muslims and NonMuslims communities. They found varying degree of awareness on Islamic banking. However, no study has investigated the awareness level of women entrepreneurs on Islamic banking. This study attempts to fill the gap by measuring the awareness level of women entrepreneurs in Quetta city. This is interesting to investigate because women in general and Quetta being a capital city of Balochistan, in particular are underserved by the financial system in Pakistan.

\section{Research Methodology}

This study is descriptive in nature as it described the extent to which women entrepreneurs are aware of Islamic banking and its products in Quetta city. This approach is deemed appropriate to observe and measure any phenomena (Combes, 2019). Additionally, the researcher compiled the business profile of Quetta's women entrepreneurs, as no such information was available regarding women entrepreneurs and their businesses in Quetta.

The researchers used survey method to examine the women entrepreneurs' awareness level about Islamic banking and its products. Survey method is an appropriate method when the researchers aim to describe or explain the characteristics of a group (Ponto, 2015). A structured questionnaire was designed to survey women entrepreneurs; the questionnaire consisted of the demographic, business profile, and awareness about Islamic banking.

For data collection, the researchers acquired the list of 201 women entrepreneurs from various sources including Small and Medium Development Authority (SMEDA), Innovative Development Organization (IDO), Incubation Center of Sardar Bahadur Khan Women University (SBKWU), National Incubation Center (NIC) Quetta, and Women Chamber of Commerce and Industries (WCCI) Quetta. The snowball sampling was also used to get further contacts of women entrepreneurs.

The researcher approached the complete list of 201 women entrepreneurs. It has been found that out of the 201 contacts, 51 contacts numbers were invalid or wrong, 21 of them didn't attend the call, and 23 didn't respond to the questionnaire. Therefore, the data was collected from 106 women entrepreneurs by personal visits, using telephonic calls, and through online questionnaires. 
The data was analyzed through descriptive analysis using SPSS. The descriptive analysis technique describes the basic features and provides the summarized information of measured data (Kenton, 2019).

\section{Analysis and Findings}

The analysis of the study is divided into three sections. Firstly, the demographic profile is presented which demonstrate the respondents' background. In the second section, the business profile is developed, which identified the business sectors of women entrepreneurs in Quetta. In the last section, awareness about Islamic banking is analyzed to measure women entrepreneurs' awareness level about Islamic banking and its products.

In this study, the researchers analyzed different aspects of the demographic profile of women entrepreneurs. Table 1 demonstrate various age groups of the women entrepreneurs. It is evident from the following Table that majority of women entrepreneurs fall under the age of 45 years. More than 50 percent of women entrepreneurs are in the age group of 25-35. This means that women in this age group are more inclined toward starting their own businesses rather than seeking jobs. It is because Govt. of Pakistan is encouraging higher education institutions to educate the university graduates regarding entrepreneurship by not only offering courses related to entrepreneurship but also organizing training sessions and Business Idea Competitions. For this purpose, Higher Education Commission (HEC) directed all universities to operationalize business incubation centers to support the young entrepreneurs (Reuters, 2019).

Table 1. Age profile of Women entrepreneurs

\begin{tabular}{lcc}
\hline Age & Frequency & Percentage \\
\hline$\leq 25$ Years & 24 & 22.6 \\
\hline $26-35$ Years & 40 & 37.7 \\
\hline 36-45 Years & 30 & 28.3 \\
\hline $46-55$ Years & 11 & 10.4 \\
\hline$\geq 56$ Years & 1 & 0.9 \\
\hline Total & 106 & 100.0 \\
\hline
\end{tabular}

describes the division of 106 women entrepenrus based on different ethnic groups. It is explicit from Table 2 that 60 percent of the women entrepreneurs are from Panjabi and Urdu speaking communities. The percentage of women entrepeneurs from local tribes (i.e., Baloch, Pashtun and Brahvi) is comparatively low. This could be due to cultural barriers because culture is one of the main hurdles for women entrepreneurship in Pakistan (CIPE, 2013). In tribal setup of Balochistan, women are exposed to strict cultural norms. Due to these cultural norms, they are not allowed to make their decisions and choose their professional careers. (Sabir, 2010).

Table 2. Ethnic Group of Women

\begin{tabular}{lcc}
\hline Ethnic Group & Frequency & Percentage \\
\hline Balochi & 12 & 11.3 \\
\hline Pashtun & 15 & 14.2 \\
\hline Brahvi & 04 & 3.8 \\
\hline Persian & 11 & 10.4 \\
\hline Panjabi & 35 & 33.0 \\
\hline Urdu & 25 & 23.6 \\
\hline Others & 04 & 3.7 \\
\hline
\end{tabular}




\begin{tabular}{lll} 
Total & 106 & 100.0 \\
\hline
\end{tabular}

\section{Business Profile}

Business profile is a report that provides an overview of the business entity, which includes business name, nature of business, business activities, business owner etc. (ARCA, 2019). In the study, the researchers developed the business profile of 106 women entrepreneurs because no detailed information existed regarding women entrepreneurs' businesses in Quetta city. This is not surprising because women entrepreneurship is one of the areas which has not received much attention in traditional societies of Pakistan. According to World Bank, Pakistan has the lowest rate of women entrepreneurship (i.e., only 1 percent) among other countries across the globe.

The type of businesses operated by women entrepreneurs in Quetta city can be divided into 11 different business sectors as shown in Table 3. It has been found that Clothing, Beauty Salon and Food-related businesses account for approximately 75 percent of overall businesses operated by women entrepreneurs in Quetta city. According to Khizar and Farrukh (2020), Clothing, Beauty Salon and Food-related businesses are the traditional sectors for women businesses. Majority of women prefer these businesses over other types of businesses.

Table 3. Nature of Businesses of Women Entrepreneurs

\begin{tabular}{lcc}
\hline Nature of Business & Frequency & Percentage \\
\hline Baking & 4 & 3.8 \\
\hline Beauty salon & 31 & 29.2 \\
\hline Clothing & 32 & 30.2 \\
\hline Event Management & 3 & 2.8 \\
\hline Food & 16 & 15.1 \\
\hline Handicrafts & 8 & 7.5 \\
\hline Jewelry & 4 & 3.8 \\
\hline Miscellaneous & 8 & 7.5 \\
\hline Total & 106 & 100.0 \\
\hline
\end{tabular}

Regarding nature of the businesses, the businesses may be classified as registered or un-registered. Williams and Shahid (2016) state that women entrepreneurs are more likely to operate in the informal sector. According to $(I L O, 2012)$, an informal sector is defined as the fact that businesses are not constituted as a legal entity, or owners have not registered their business with any authorized body for tax purposes. It is evident from Table 4 that 68 percent of the women entrepreneurs of Quetta city are operating informal businesses. In literature, it has been also identified that most of the women entrepreneurs in Pakistan operate informal businesses. Goheer et al. (2003) argue that majority of women are hesitant to register their businesses with legislative bodies because their businesses are small scale and home-based. Additionally, documentation is required for getting registered.

Table 4, Nature of Businesses of Women Entrepreneurs

\begin{tabular}{ccc}
\hline Business sector & Frequency & Percentage \\
\hline Registered & 34 & 32.0 \\
\hline Un-registered & 72 & 68.0 \\
\hline Total & 106 & 100.0 \\
\hline
\end{tabular}

Table 5 depicts that approximately 70 percent of women entrepreneurs have home-based businesses. They either sell their products online using social media or arranging stalls in different exhibitions. On the contrary, only 30 percent of women entrepreneurs have business outlets in various locations of 
Quetta city. These outlets include Boutiques, Beauty Salons, and Restaurants located in a different areas of Quetta city. Due to small scale businesses and un-affordability of business outlets, majority of the women started their online businesses and promoting their products through social media. The new era of technology provides great opportunities for people to start and nourish their business by using less financial resources (Sarfaraz, 2017).

Table 5. Business Operations of Women Entrepreneurs

\begin{tabular}{lcc}
\hline Business operation & Frequency & Percentage \\
\hline Home-Based & 74 & 69.8 \\
\hline Physical outlet & 32 & 30.2 \\
\hline Total & 106 & 100.0 \\
\hline
\end{tabular}

Regarding means of finance, majority of the women entrepreneurs started their businesses from personal financing. Shaharuddin et al. (2005) identified that significant number of the SMEs owners started their business with personal financing; which means initial financing from bank is relatively low in case of SMEs. The results given in Table 6 exhibited that 68.9 percent of respondents instigated their businesses by personal financing, 29.2 percent through family/friends financing. However, only a small fraction of 1.9 percent of women entrepreneurs commenced their business by obtaining financing from the banks. Due to interest factor and bank criteria for financing, most of the women prefers to start their business with their personal, and family financing (Syed, 2010).

Table 6. Initial Capital for Businesses of Women Entrepreneurs

\begin{tabular}{lcc}
\hline Initial Capital for Business & Frequency & Percentage \\
\hline Personal & 73 & 68.9 \\
\hline Family/Friends Financing & 31 & 29.2 \\
\hline Loan from Bank & 02 & 1.90 \\
\hline Total & 106 & 100.0 \\
\hline
\end{tabular}

\section{Analysis of Awareness about Islamic Banking and its Products}

In this study, numerous questions were probed from women entrepreneurs about Islamic banking to assess their awareness regarding Islamic banking and its product. The questionnaire was categorized into six sections based on awareness about Islamic banking, Islamic principles, Shariah board, Islamic banking products, modes of finance, and comparison of Islamic banking with their conventional counterparts.

The first about and main question about awareness of Islamic banking was asked from 106 women entrepreneurs. The result as shown in Figure 2 depicts that only 64 women entrepreneurs were aware about Islamic banking, whereas 42 women entrepreneurs were not aware about it. In Pakistan, the Islamic banking system is introduced since nearly two decades, yet the awareness level among women entrepreneurs is relatively low. Such low awareness level among women entrepreneurs could be due to insufficient marketing strategies as up till now Islamic banks are incapable to launch awareness campaigns for the women in Pakistan (Ayub, 2013). Based on awareness of women entrepreneurs about Islamic banking, the sample size decreased to 64 respondents. The researchers queried the remaining questions from only those women entrepreneurs who were aware about Islamic banking. 


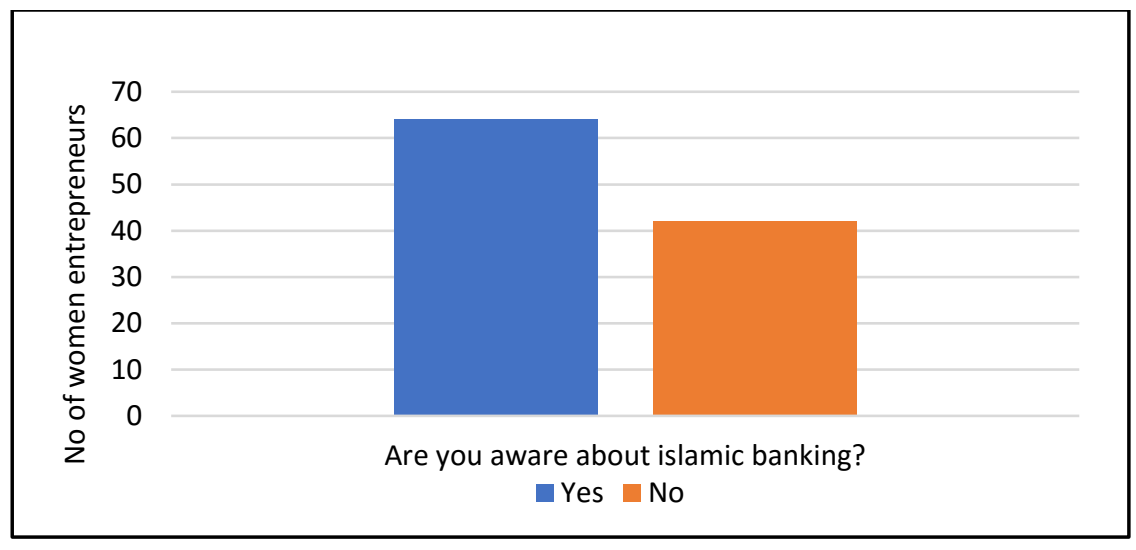

Figure 2. Awareness about Islamic Banking

Although majority of the women entrepreneurs (i.e., 60 percent) knew about Islamic banking but the number of women entrepreneurs further trimmed down as we moved to our second question i.e., Islamic banking operations are based on Islamic principles. From 64 women entrepreneurs, only 44 of them were aware that Islamic banking is based on Islamic principles as shown in Figure 3. The results found to be in line with a study conducted on general society that majority of the respondents were aware with the existence of Islamic banking. However, limited respondents knew about the way Islamic banks operate (Shaikh et al., 2017). Based on the responses of women entrepreneurs, the sample size further reduced to 44 respondents. The researchers asked the remaining questions from only those women entrepreneurs who were not only aware about Islamic banking existence but also knew that it is based on Islamic principles.

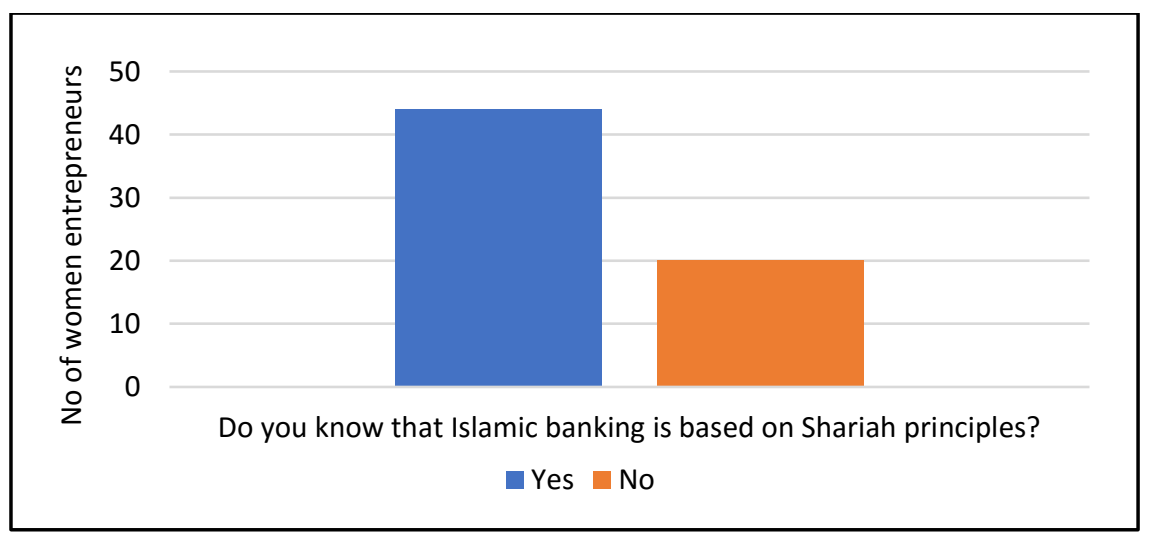

Figure 3. Awareness about Islamic Banking is based on Islamic principles

The queries regarding various aspect of Islamic principles, which the researchers asked from the women entrepreneurs, were mainly focused on Riba (interest), profit-loss sharing principles, uncertainty (gharar) and investment in halal businesses. Being a Muslim and resident of Islamic Republic of Pakistan, the majority of women entrepreneurs were aware about the concept of Riba and its prohibition in Islam (see Figure 4). This may be because Riba and its prohibition is not only stated in Quran, Hadith and in fiqh books but it has also been discussed in length by Islamic scholars (Ali, 2007). However, only 34 of women entrepreneurs knew about Riba-free banking activities. 


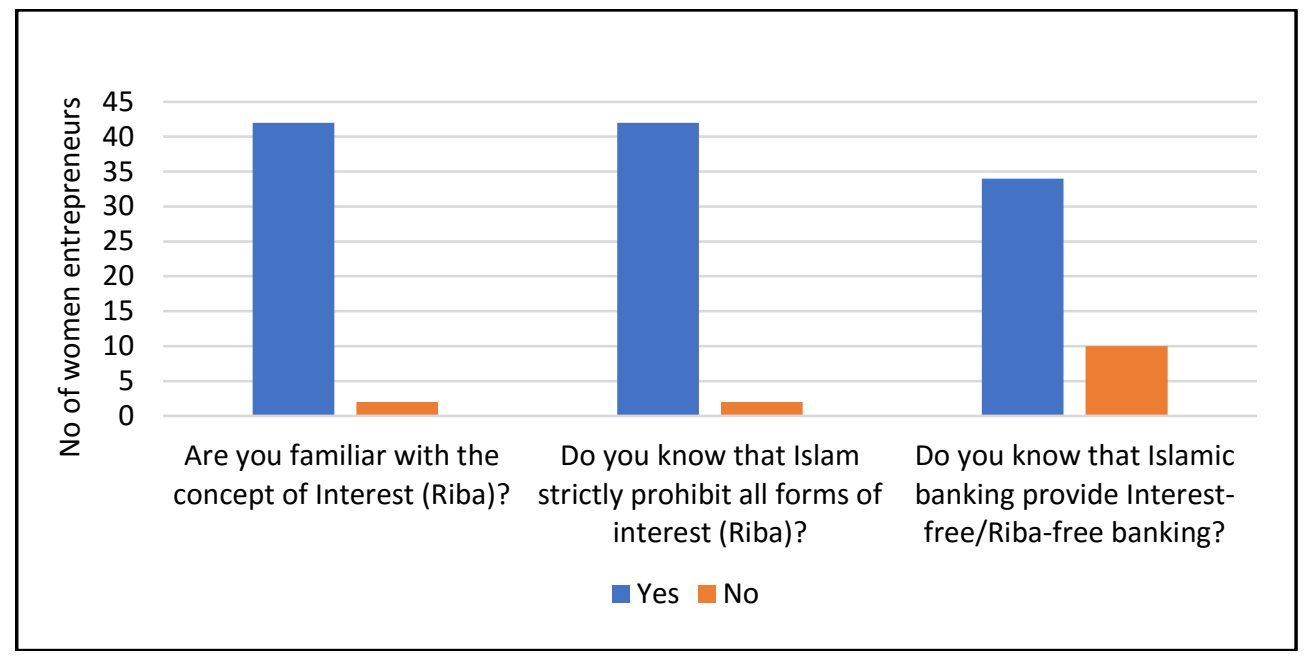

Figure 4. Awareness about Riba about Interest-free banking

Regarding profit-loss sharing principle, the researchers found that almost half of the women entrepreneurs knew that Islamic banking and its returns are based on profit-loss sharing principle. While 15 of them were informed about the risk-sharing model as shown in Figure 5. The results demonstrated that awareness regarding Islamic banking operations was relatively low. Such low level of awareness could be due to marketing strategies, as Islamic banks are unable to properly target the unaware segment of general society in order to create their awareness regarding Islamic baking and its operations which would ultimately increase market share of Islamic banks (Rustam et al., 2011).

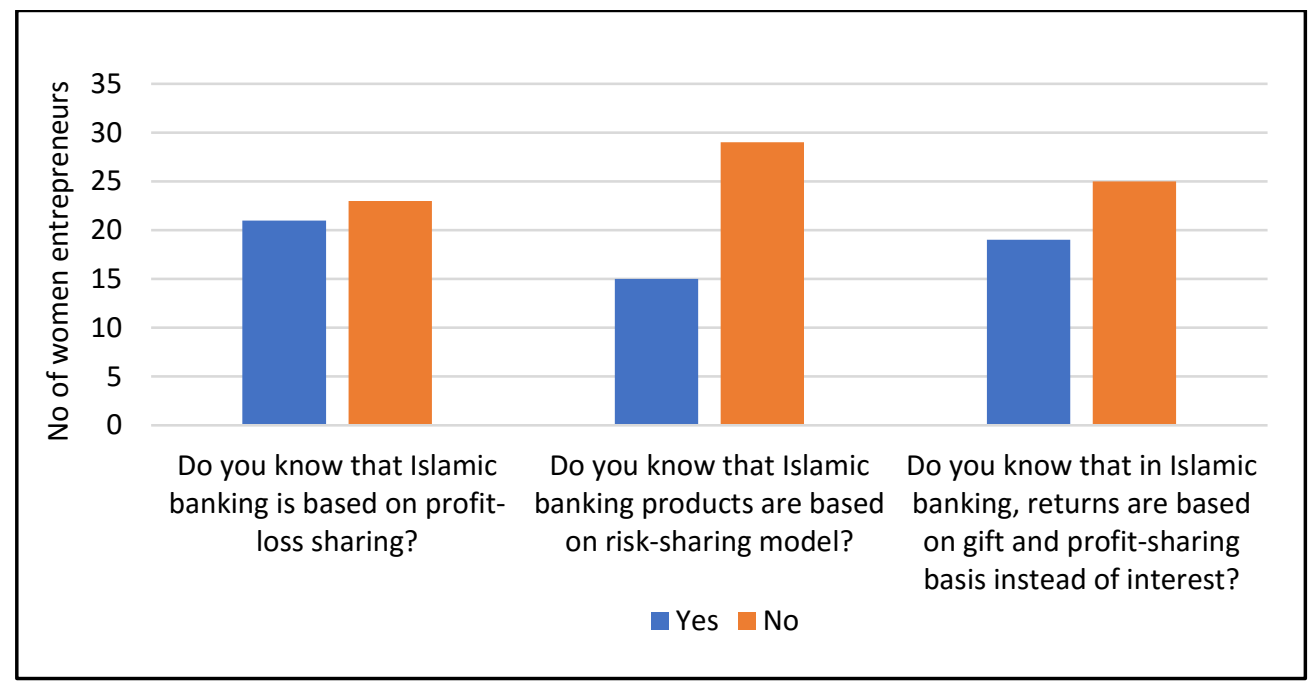

Figure 5. Awareness about profit -loss and Risk-sharing principle

Concerning the awareness about prohibition of uncertainty (gharar) and investment by the Islamic banks in Halal businesses, only 14 women entrepreneurs were aware about the fact that Islamic banks avoid uncertainty (gharar) in all forms of transactions (see Figure 6). Almost half of them knew that Islamic banks invest only in Halal businesses. 


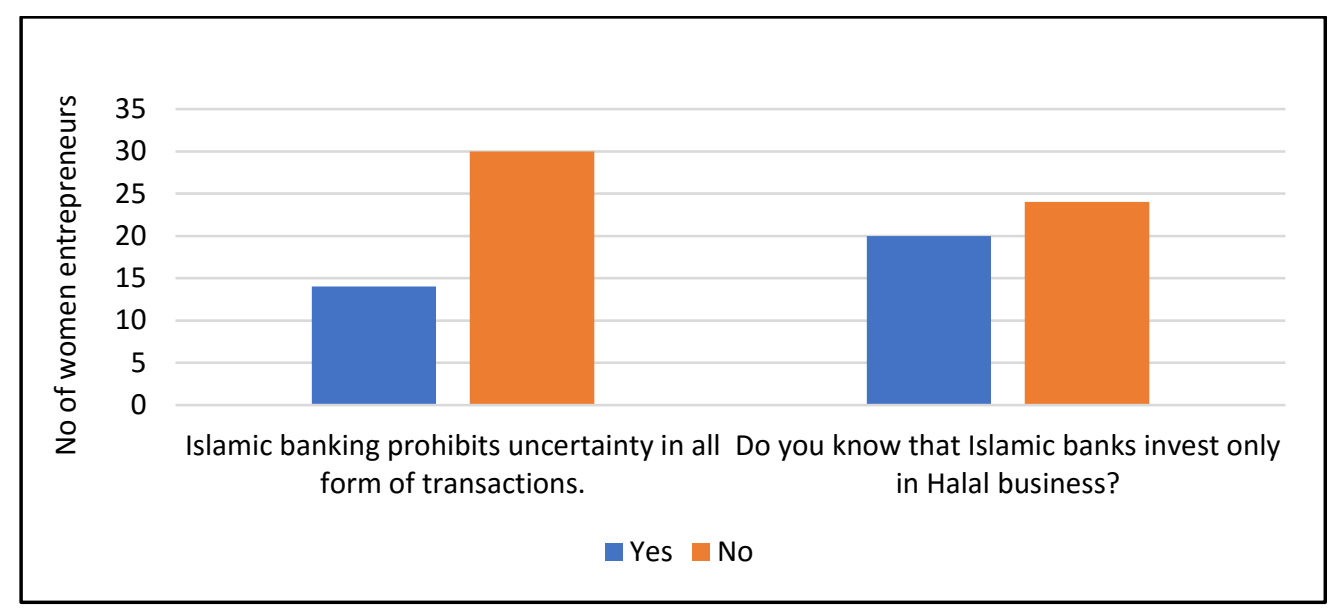

Figure 6. Awareness about prohibition of uncertainty and investment in Halal Business

Based on the responses of 44 women entrepreneurs regarding various aspects of Islamic principles (such as Riba \& its prohibition, profit-loss sharing principle, risking sharing, uncertainty (gharar) and investment in Halal businesses), the results (as shown in Figure $4-6$ ) found to be mixed as discussed previously. Although majority of them were well informed about concept of Riba and its prohibition in Islam. But it has been found that there were only 21 women entrepreneurs who positively answered all the questions related to different aspects of Islamic principles. The rest of them were not familiar with different aspects of Islamic principles. Insufficient knowledge about Islamic principles pertaining to Islamic finance and its various aspects could be one of the reasons behind such unawareness as highlighted by (Hidayat, 2020).

Due to lack of understanding about Islamic principles and its different aspects, the sample size reduced to 21 so the remaining questions were asked from those women entrepreneurs who not only were aware about existence of Islamic banking but also were well informed about Islamic principles and its various aspects. The researchers queried the 21 women entrepreneurs about Shariah board and its functions. It has been found that all of the women entrepreneurs were aware about Shariah board of Islamic banks and its roles in evaluation of Islamic banking activities and product \& services as depicted in Figure 7.

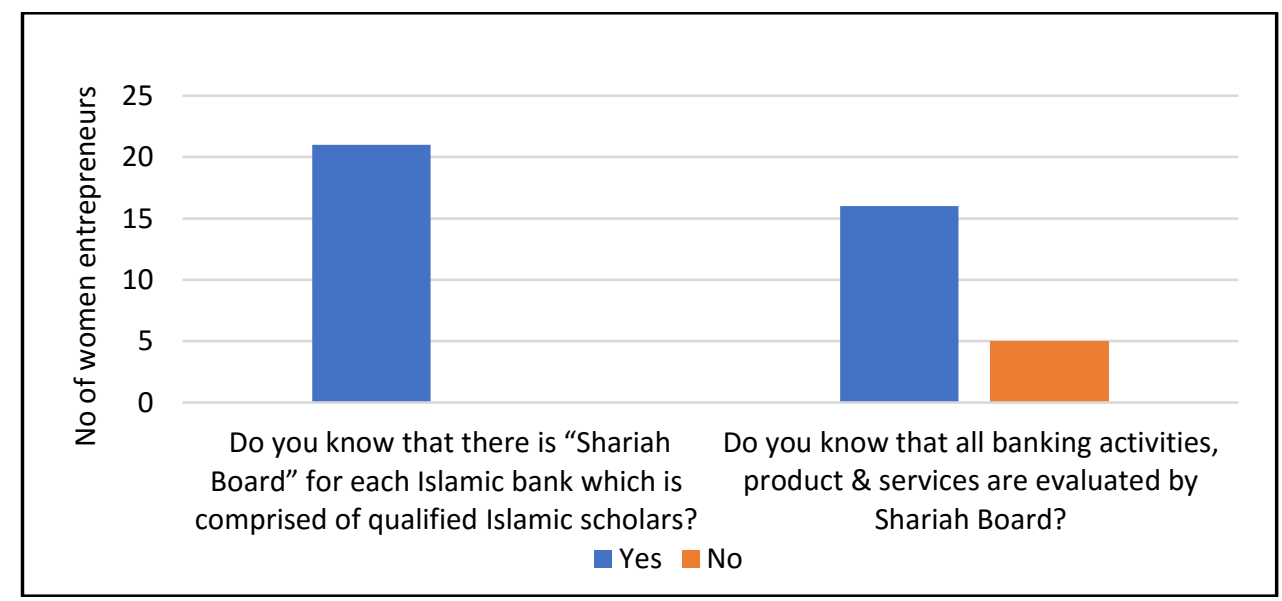

Figure 7. Awareness about Shariah Board

The responses of 21 women entrepreneurs about products and services offered by the Islamic banks are shown in Figure 8. It is evident from the results that almost half of the women entrepreneurs were aware about the different products offered by the banks. Such products included saving accounts, investment schemes/funds and Takaful. These results found to be consistent with the literature (Khafafa \& Shafi, 2013). 


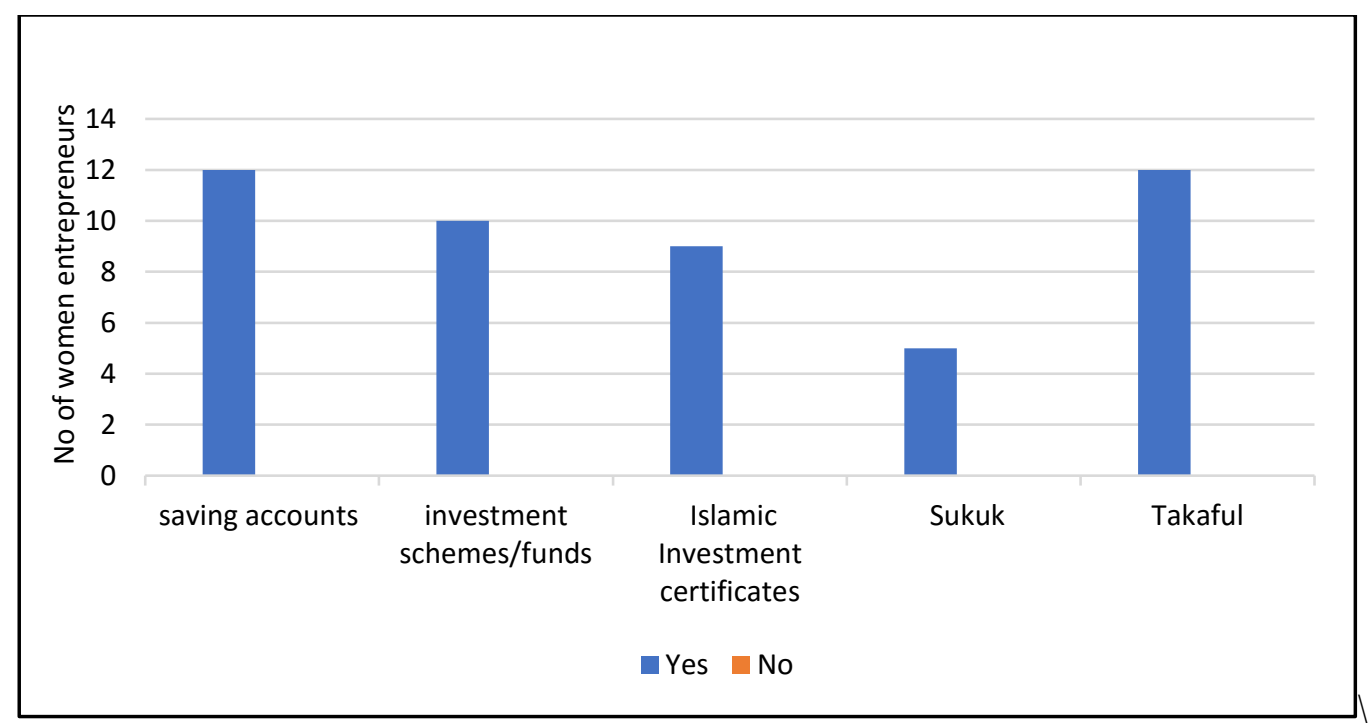

Figure 8. Awareness about Islamic banking products

Based on the results discussed in the previous para, the sample size shrank to the 12 women entrepreneurs. The research inquired the question about the modes of Islamic finance from remaining 12 women entrepreneurs. These women entrepreneurs were well aware about the Islamic principles and its various aspects, Shariah board, and products offered by the Islamic banks. It is evident from the results as shown in Figure 9 that most of the women entrepreneurs had high level of understanding about two of the modes of Islamic finance used by Islamic banks in structuring their products which included Mudarabaha and Musharakah. However, their awareness about Murabahah, Istisna, Salam and Diminishing Musharakah found to be quite low Ijara, Salam etc. These results were also in line with the findings of Raza and Azeem (2014), which demonstrated that banking customers were informed about Mudarabaha and Musharakah, but they do not have high level of awareness about other modes of Islamic finance which included Istisna, Murabahah etc.

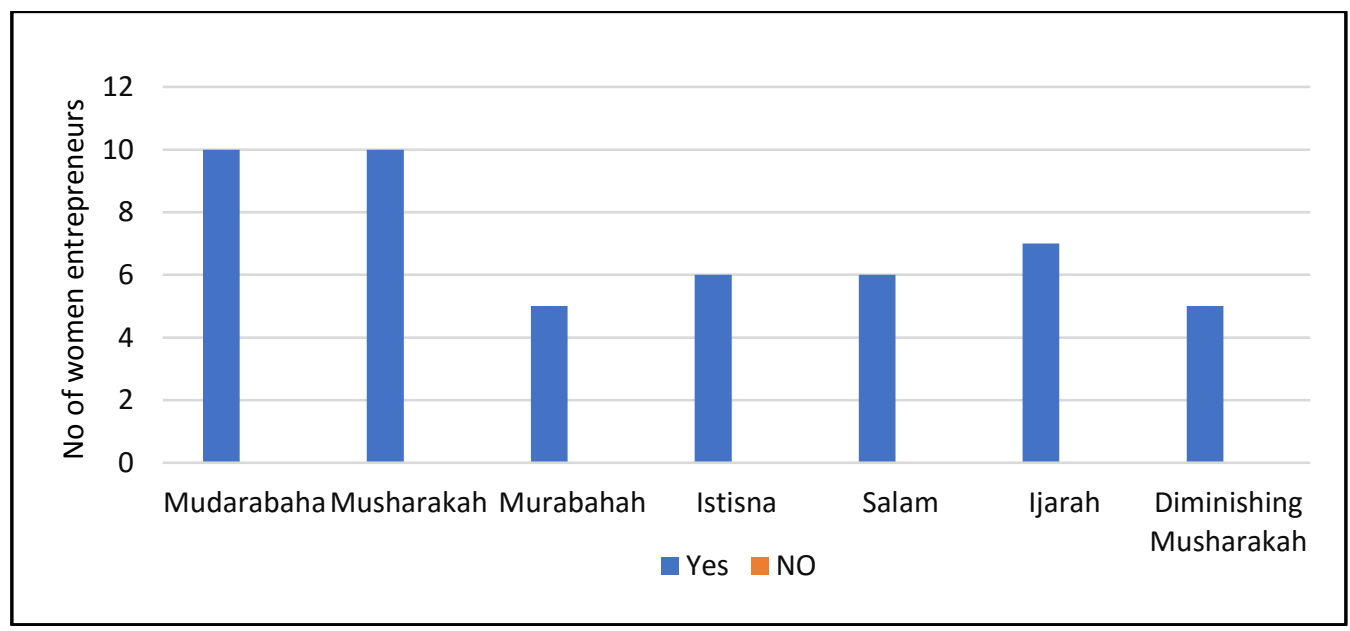

Figure 9. Awareness about Islamic modes of finance

Finally, the researchers asked the most aware 10 women entrepreneurs about the comparison of Islamic banks with conventional ones. It is evident from Figure 10 that all 10 women entrepreneurs deemed Islamic banks different from their conventional counterparts.

The study analyzed that there are 10 women entrepreneurs who are highly aware about Islamic banking, Islamic principles, Shariah board, Islamic banking products, and Islamic modes of finance. 


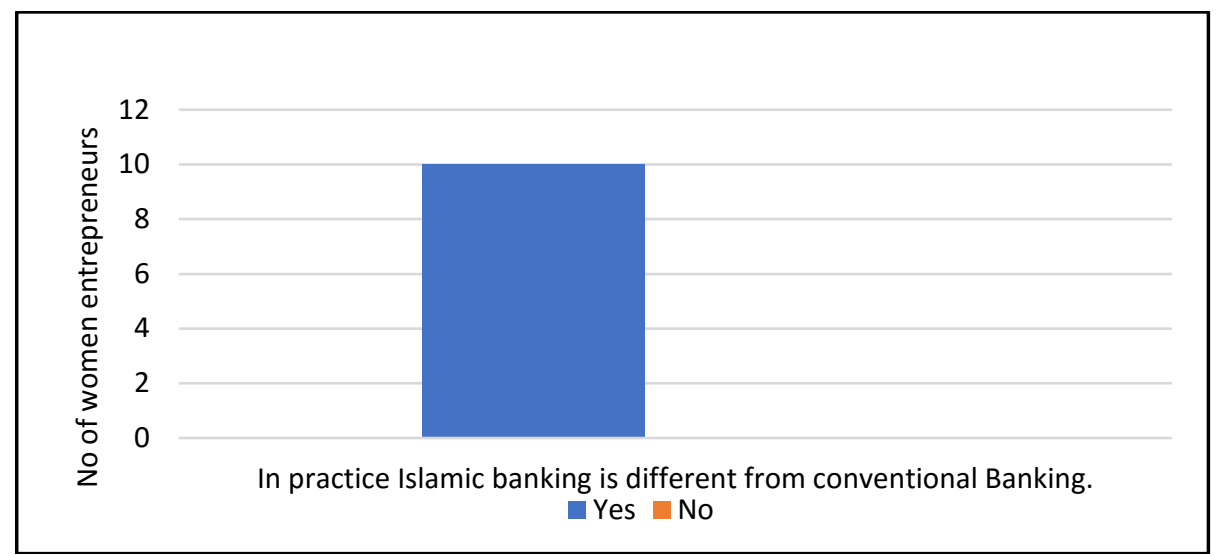

Figure 10. Awareness about Islamic modes of finance

\section{Conclusion}

The paper investigated the awareness level of women entrepreneurs regarding Islamic banking and its products in Quetta city. Additionally, the researcher compiled business profile of Quetta-based women entrepreneurs. The researchers identified the 11 multiple sectors where women entrepreneurs are operating their businesses and found that majority of women entrepreneurs are engaged in informal businesses.

Moreover, to examine the awareness level, the researcher conducted a survey and found that the overall awareness about Islamic banking among women entrepreneurs is relatively low. The study analyzed that around 60\% women entrepreneurs knew Islamic banking however the response regarding the further quires were diminished as the researcher moved to the next sections. Regarding various aspect of Islamic principles, the study identified that majority of women entrepreneurs were aware about the concept of Riba and its prohibition in Islam. However, the study found mixed responses for other aspects of Islamic principles including profit-loss sharing, uncertainty (gharar), and investment in halal business. The findings revealed that only a few numbers of women entrepreneurs were familiar with different aspects of Islamic principles and about Shariah board's role in Islamic banking. The results revealed that around $11 \%$ women entrepreneurs were aware of different products offered by Islamic banks. Similarly, around 09\% of women entrepreneurs were aware with various financial products such as Mudarabaha, Musharkaha, Ijarah, Salam, Istisna, and Diminishing Musharakah. The study found that only 10 women entrepreneurs (i.e., 09\%) are highly aware about Islamic banking, Islamic principles, Shariah board, Islamic banking products, and Islamic modes of financing.

The study analyzed that due to lack of knowledge and insufficient marketing strategies of Islamic banks, majority of women entrepreneurs were unaware with different aspects of Islamic banking. The study suggested that Islamic banks should start new marketing strategies by targeting the neglected sectors. Therefore, with the collaboration of the State Bank of Pakistan, the Islamic banking industry should initiate awareness campaigns, arrange workshops, seminars, and training sessions to increase awareness regarding Islamic banking among women entrepreneurs and general public.

\section{Reference}

Ahmad, M., Palil, R., Bakar, A. B. A., \& Dolah, N. H. (2015). Literature Review On The Knowledge Of Islamic Banking Products Among Muslim Entrepreneurs. International Journal of Business, Economics and Law, 6(2), 4.

Ahmed, J., Bano, S., \& Dawood, L. (2017). Understanding Islamic Banking: The Perception and Thoughtfulness of Customers about Islamic Banking in the Context of Balochistan. Journal of Islamic Banking and Finance, 34(3).

Ali, F. (2016). Awareness about Islamic Banking System. KASBIT Business Journal (KBJ), 9, 94-130. 
ARCA. (2019). Business Profile. Accounting and Corporate Regulatory Authority. https://www.acra.gov.sg/how-to-guides/buying-information/business-profile

Arshad, M., Aslam, S., Razi, A., \& Ali, S. A. (2011). A COMPARATIVE ANALYSIS OF BANKERS' PERCEPTION ON ISLAMIC BANKING IN PAKISTAN. 12.

Ayub, R. (2013). Perception Of Working Women Towards Islamic Banking In Pakistan. RADS Journal of Social Sciencess \& Business Management, 1(1), 7-12.

Bashir, M. S. (2013). Analysis of Customer Satisfaction with the Islamic Banking Sector: Case of Brunei Darussalam. 2(10), 38-50.

Buchari, I., Rafiki, A., \& Qassab, M. A. H. A. (2015a). Awareness and Attitudes of Employees towards Islamic Banking Products in Bahrain. Procedia Economics and Finance, 30, 68-78. https://doi.org/10.1016/S2212-5671(15)01256-3

Buchari, I., Rafiki, A., \& Qassab, M. A. H. A. (2015b). Awareness and Attitudes of Employees towards Islamic Banking Products in Bahrain. Procedia Economics and Finance, 30, 68-78. https://doi.org/10.1016/S2212-5671(15)01256-3

Chaouch, N. (2017). An Exploratory Study of Tunisian Customers' Awareness and Perception of Islamic Banks. International Journal of Islamic Economics and Finance Studies, 26.

Cheteni, P. (2014). Awareness of Islamic Banking Products and Services among Consumers in South Africa. Mediterranean Journal of Social Sciences. https://doi.org/10.5901/mjss.2014.v5n9p96

Chowdhury, M. N. H., \& Arifuzzaman, S. M. (2013). Examining Awareness Regarding Islamic Banking among Business Graduates in Bangladesh. Journal of Islamic Economics , Banking and Finance, 9(1), 77-88. https://doi.org/10.12816/0001594

Combes, S. mc. (2019, May 15). Descriptive Research Design | Definition, Methods and Examples. Scribbr. https://www.scribbr.com/methodology/descriptive-research/

CIPE (2013). Barriers to Women's Entrepreneurship in Pakistan. Center for International Private Enterprise. $\quad$ https://www.cipe.org/blog/2013/03/11/barriers-to-womens-entrepreneurship-inpakistan/

Dourish, P., \& Bellotti, V. (1992). Awareness and coordination in shared workspaces. Proceedings of the 1992 ACM Conference on Computer-Supported Cooperative Work - CSCW '92, 107-114. https://doi.org/10.1145/143457.143468

Fouladi, H. (2017, August 31). Cultural and Tribal Barriers in Balochistan. WRN. https://www.womensregionalnetwork.org/single-post/2017/10/25/cultural-and-tribal-barriers-inbalochistan

Gafoor, K. A. (2012). Considerations in the Measurement of Awareness. Emerging Trends in Education, 6.

Gait, A. H., \& Worthington, A. C. (2007). An Empirical Survey of Individual Consumer, Business Firm and Financial Institution Attitudes towards Islamic Methods. 23.

Gait, A., \& Worthington, A. (2008). An empirical survey of individual consumer, business firm and financial institution attitudes towards Islamic methods of finance. International Journal of Social Economics, 35(11), 783-808.

https://doi.org/10.1108/03068290810905423

Gerrard, P., \& Barton Cunningham, J. (1997). Islamic banking: A study in Singapore. International Journal of Bank Marketing, 15(6), 204-216. https://doi.org/10.1108/02652329710184433

Goheer, N. A. (2003). Women entrepreneurs in Pakistan: How to improve their bargaining power. InFocus Program on Boosting Employment through Small Enterprise Development, International Labour Office.

Göksu, A., \& Becic, A. (2012). Awareness of Islamic Banking in Bosnia and Herzegovina. International Research Journal of Finance and Economics, 100, 26-39.

Hanif, M., \& Iqbal, A. M. (2010). Islamic Financing and Business Framework: A Survey (No. 4). 15(4), 16.

Haron, S., Ahmad, N., \& Planisek, S. L. (1994). Bank Patronage Factors of Muslim and Non-Muslim Customers. International Journal of Bank Marketing, 12(1), 32-40. https://doi.org/10.1108/02652329410049599 
Hidayat, S. E., Rafiki, A., \& Svyatoslav, S. (2020). Awareness of financial institutions' employees towards Islamic finance principles in Russia. PSU Research Review, 4(1), 45-60. https://doi.org/10.1108/PRR-08-2019-0026

ILO. (2012). Statistical update on employment in the informal economy. International Labour Organization. http://www.ilo.org/global/statistics-and-databases/WCMS_182504/lang en/index.htm

Imran, M., Samad, S. A., \& Masood, R. (2014). Awareness Level of Islamic Banking in Pakistan's Two Largest Cities. 1, 20.

Islam, J. U., \& Rahman, Z. (2017). Awareness and willingness towards Islamic banking among Muslims: An Indian perspective. International Journal of Islamic and Middle Eastern Finance and Management, 10(1), 92-101. https://doi.org/10.1108/IMEFM-01-2016-0017

Islamic Banking Bulletin. (2018). Islamic Banking Department, State Bak of Pakistan.

Islamic Banking Bulletin. (2020). Islamic Banking Department, State Bank of Pakistan. http://www.sbp.org.pk/ibd/bulletin/2020/Mar.

Iqbal, Z. (2019, October 9). SME growth in Pakistan: What is missing? Daily Times. https://dailytimes.com.pk/481200/sme-growth-in-pakistan-what-is-missing/

Kazmi, K. H. (2018, October 28). Significance of women entrepreneurship in Pakistan. Pakistan \& Gulf Economist. http:/www.pakistaneconomist.com/2018/10/29/ significance-of-womenentrepreneurship-in-pakistan/

Kenton, W. (2019). Descriptive Statistics. Investopedia.

https://www.investopedia.com/terms/d/descriptive_statistics.asp

Khafafa, A. J., \& Shafii, Z. (2013). Customer Satisfaction and Islamic Banking Awareness in the Islamic Banking Window System in Libya. Middle-East Journal of Scientific Research 13 (Research in Contemporary Islamic Finance and Wealth Management), 7.

Khan, M. S. N., Hassan, M. K., \& Shahid, A. I. (2007). Banking Behavior of Islamic Bank Customers in Bangladesh. Journal of Islamic Economics, Banking and Finance, 3(2), 36.

Khattak, N. A., \& Rehman, K. U. (2010). Customer satisfaction and awareness of Islamic banking system in Pakistan. African Journal of Business Management, 4(5), 662-671.

Khizar, A., \& Farrukh, S. (2020). Female Economic Participation in Pakistan. Case-Study. Karandaaz. https://karandaaz.com.pk/wp-content/uploads/2020/04/Case-Study.

Lim, S. (2019). Understanding Islamic Banking. Investopedia. https://www.investopedia.com/terms/i/islamicbanking.asp

Lujja, S., Mohammed, M. O., \& Hassan, R. (2018). Islamic banking: An exploratory study of public perception in Uganda. Journal of Islamic Accounting and Business Research, 9(3), 336-352. https://doi.org/10.1108/JIABR-01-2015-0001

Markets. (2019). Global Islamic Finance Markets Report 2019: Islamic Banking is the Largest Sector, Contributing to 71\%, or USD 1.72 Trillion. GlobeNewswire News Room. http://www.globenewswire.com/news-release/2019/03/20/1758003/0/en/Global-Islamic-FinanceMarkets-Report-2019-Islamic-Banking-is-the-Largest-Sector-Contributing-to-71-or-USD-1-72Trillion.html

Metawa, S. A., \& Almossawi, M. (1998). Banking behavior of Islamic bank customers: Perspectives and implications. International Journal of Bank Marketing, 16(7), 299-313. https://doi.org/10.1108/02652329810246028

Naser, K., Jamal, A., \& Al-Khatib, K. (1999). Islamic banking: A study of customer satisfaction and preferences in Jordan. International Journal of Bank Marketing, 17(3), 135-151. https://doi.org/10.1108/02652329910269275

Noonari, S., \& Memon, Ms. I. (2015). Knowledge and Perception of Students Regarding IslamicBanking: A Case Study of Hyderabad Sindh Pakistan. https://doi.org/10.13140/RG.2.1.3030.4485

Ponto, J. (2015). Understanding and Evaluating Survey Research. Journal of the Advanced Practitioner in Oncology, 6(2), 168-171.

Rammal, H. G., \& Zurbruegg, R. (2007). Awareness of Islamic banking products among Muslims: The 
case of Australia. Journal of Financial Services Marketing, 12(1), 65-74. https://doi.org/10.1057/palgrave.fsm.4760060

Raza, H., \& Azeem, M. (2014). 234629802.pdf. Research Journal of Finance and Accounting, 5(3), Article 3. https://core.ac.uk/download/pdf/234629802.pdf

Reiff, G. (2018). Islamic Banking - History, Overview \&amp; Future Table of Content. https://www.academia.edu/33493111/Islamic_Banking_History_Overview_and_Future_Table_o f_Content

Reuters. (2019). Youth, women spur social business growth in Pakistan: Global poll. DAWN.COM. https://www.dawn.com/news/1512360

Rustam, S., Bibi, S., Zaman, K., \& Rustam, A. (2011). Perceptions of Corporate Customers Towards Islamic Banking Products and Services in Pakistan. The Romanian Economic Journal, 41, 107123.

Saini, Y., Bick, G., \& Abdulla, L. (2011). Consumer awareness and usage of islamic banking products in South Africa. South African Journal of Economic and Management Sciences, 14(3), 298-313. https://doi.org/10.4102/sajems.v14i3.193

Saleem, M., Ashraf, A., Kashif, M., \& Umair, M. (2018). Attitude and Perception of Employees towards Islamic Banking. IOSR Journal of Business and Management (IOSR-JBM), 18.

Sabir, Dr. A. R. (2010). MULTICULTURALISM: A CASE STUDY OF BALOCHISTAN | Balochi Linguist. BALOCHISTAN REVIEW, https://balochilinguist.wordpress.com/2013/04/21/multiculturalism-a-case-study-of-balochistan/

Sarfaraz, E. (2017). Pakistan's young entrepreneurs tap social media to grow business. World Asia. https://gulfnews.com/world/asia/pakistan/pakistans-young-entrepreneurs-tap-social-media-togrow-business-1.2022254

SBP. (2019). State Bank of Pakistan. http://www.sbp.org.pk/ibd/faqs.asp

Shaikh, D. M. A., Shah, Dr. A. B., \& Bhaghal, G. U. (2017). AWARENESS OF ISLAMIC BANKING IN THE SOCIETY: A CASE STUDY OF HYDERABAD. The Government: Research Journal of Political Science, 5(Supplementary Edition), 133-142.

Shaharuddin, Dr. A., Hamid, S. A., Safian, Y. H. M., \& Muhamad Muda, P. D. D. (2005). A Study on Small and Medium-Sized Enterprises Perception Towards Islamic Banking Products. http://ddms.usim.edu.my:80/jspui/handle/123456789/5332

Susruthan, N. K., \& Priyadharshany, D. Aj. (2018). Role of Women Entrepreneurship. International Journal of Pure and Applied Mathematics, 120(05), 12.

Syed, J. (2010). Women and small business entrepreneurship in Pakistan. In International Research Handbook on Successful Women Entrepreneurs (pp. 117-131). Cheltenham \& New York: Edward Elgar.

Tonido. (2009). Brand Awareness and Perception. Tonido. https://www.tonido.com/blog/index.php/2009/04/30/brand-awareness-andperception/\#.XdUNLdVKiM8

William, C. C., \& Round, J. (2009). Evaluating informal Entrepreneur's Motives: Some Lessons from Moscow. International Journal of Entrepreneurial Behaviour and Research, 15(1), 94-107.

Williams, C. C., \& Shahid, M. S. (2016). Informal entrepreneurship and institutional theory: Explaining the varying degrees of (in)formalization of entrepreneurs in Pakistan. Entrepreneurship \& Regional Development, 28(1-2), 1-25. https://doi.org/10.1080/08985626.2014.963889

Yaur, M. k. (1973). THE CONCEPT OF AWARENESS. Journal of Thought, 8(4), 259-269.

Zainol, Z. (2008). A Comparative Analysis of Bankers' Perceptions on Islamic Banking. International Journal of Business and Management, 3, 12. 